\title{
Justice Peters' Contribution to Family and - Community Property Law
}

\author{
Brigitte M. Bodenheimer*
}

Important areas of California's family tort and marital property law as well as aspects of its divorce and annulment law have been shaped by Justice Peters' incisive pen. Perhaps his most dramatic contribution is the judicial pronouncement that a major part of California's quasi-community property legislation is constitutional. This article first discusses this significant development, as well as Justice Peters' holdings concerning the revival of community property. It then analyzes his important decisions on interspousal tort immunity. Finally, it reviews a number of significant opinions by the Justice on damages for loss of consortium, child support, and decisions relating to public policy and the termination of marriage.

\section{QUASI-COMIUNITY PROPERTY}

Addison v. Addison, ${ }^{\mathrm{l}}$ written by Justice Peters for a nearly unanimous court, ${ }^{2}$ is a milestone in California Supreme Court history. It makes the first hole in the wall of rigid doctrine which stood unscarred since 1897 and which blocked the way of orderly progress toward equitable property arrangements for California spouses. The legislature had succeeded in a number of respects in improving and modernizing the marital property system both for couples long resident in California and for those who came to California more recently; but the legislature's task was an exceedingly difficult one

* Research Associate in Law, University of California, Davis; former Associate Professor of Law, University of Utah. J.U.D.. University of Heidelberg; LL.B., University of Washington. Member of the Bars of Washington and Utah.

1. 62 Cal. 2d 558, 399 P.2d 897, 43 Cal. Rptr. 97 (1965). See generally Gardner, Marital Property and the Conflict of Laws: The Constitutionality of the "Quasi-Community Property" Legislation. 54 CALIF. L. Rev. 252 (1966); Knutson, Calijornia Community Property Laws: A Plea for Legislative Study and Reform. 39 S. CAL. L. Rev. 240 (1966); Lay, Marital Property Rights of the Non-Native in a Community Property State, 18 HAST. L.J. 295, 307-17 (1967); Note, Retroactive Application of California's Community Property Statutes. 18 Stan. L. Rev. 514 (1966). For a discussion of the 1961 legislation involved in the case, see Schreter (now Kay), "Quasi-Community Property" in the Conflicl of Laws. 50 CALIF. L. Rev. 206 (1962).

2. Justice McComb dissented.

3. See generally 1 B. Armstrong, California Family Law 431-855 (1953 and Supp. 1966). [hereinafter cited as ARMSTRONG]. 
since many of its efforts were thwarted by decisions declaring a new law unconstitutional or holding a law's complete effectiveness in abeyance for as long as 50 or more years. ${ }^{4}$

To newcomers to California like my husband and myself who arrived with possessions "which would have been community property" had they been acquired while we were domiciled here, the idea that we now have, in addition to sorne community and separate property, belongings which are separate property today, but may be "quasi-community property" tomorrow, and this for some purposes, but not for others, ${ }^{6}$ is a rather startling one. The story behind these legal complexities is as fascinating as it is at times disconcerting.

It begins with Spreckles v. Spreckels, ${ }^{7}$ decided in 1897. A law passed in 1891 required that a husband obtain his wife's written consent before making gifts of community property. ${ }^{8}$ In Spreckles, the Supreme Court of California held this law to be inapplicable to community property given away by a husband in 1893 since the property in question had been acquired by the marital community before the law's enactment. The court stated that any retroactive restriction upon the husband's property right would be unconstitutional. The decision was based, as has been pointed out by Professor Armstrong, ${ }^{9}$ on a concession by counsel of the constitutional point which was neither seriously considered nor explicitly decided by the court. Nevertheless, this weak decision became the matrix of a whole string of cases ${ }^{10}$ which solidified the California constitutional doctrine of prospective

4. See Armstrong, "Prospective" Application of Changes in Community Property" Control-Rule of Property or Constitutional Necessity?. 33 CALIF. L. Rev. 476 (1945) [hereinafter cited as Armstrong, "Prospective" Application]; Comment, Community and Separate Property: Constitutionality of Legislation Decreasing Husband's Power of Control over Property' Already Acquired. 27 CaLif. L. Rev. 49 (1938).

5. CAL. CIV. CODE $\$ 140.5$ (West Supp. 1968).

6. See ch. 636, [1961] Cal. Stats. 1838, which amends portions of the Civil Code, the Probate Code, and the Revenue and Taxation Code in order to convert some marital property acquired elsewhere into quasi-community property for selected occasions or purposes. This statute adds, for example, section 140.7 of the Civil Code, which reads: "As used in sections $141,142,143,146,148,149$ and 176 of this code, 'separate property' does not include quasjcommunity property." Ch. 636, $\$ 3$, [1961] Cal. Stats. 1839.

See Addison v. Addison, 62 Cal. 2d 558, 399 P.2d 897, 43 Cal. Rptr. 97 (1965). Also see Estate of Rogers, 245 Cal. App. 2d. 101, 53 Cal. Rptr. 572 (1966), which shows that after conversion of out-of-state property into quasi-community property the rules with respect to community property do not necessarily apply. (A heavier inheritance tax burden on quasicommunity property was upheld in this case.)

7. 116 Cal. 339, 48 P. 228 (1897).

8. Ch. 220, [1891] Cal. Stats. 425, amending CAl.. Civ. CODE $\$ 172$.

9. Armstrong, "Prospective" Application, supra note 4, at 497-99.

10. See 1 Armstrong, supra note 3, at 592-98. 
application of changes in community property laws. ${ }^{11}$ Since 1927 when the legislature recognized the wife's vested interest in community property, ${ }^{12}$ this doctrine has not only postponed the complete effectiveness of changes favoring the wife but has postponed the effectiveness of those benefiting the husband as well. ${ }^{13}$ The rule is particularly onerous because of its corollary that any property which can be traced back to an acquisition made before the legislative change partakes of the immutable character of the original property. ${ }^{14}$

There was one brief intermezzo in 1933, a sudden flare-up of contrary constitutional opinion, when the Supreme Court of California in the first Thornton case ${ }^{15}$ upheld an amendment to section 164 of the Civil Code which transformed certain marital property acquired in common law states into California community property. The court declared that the amendment did not interfere with vested property rights, and even if it did, "such legislation is permissible under the power of the Legislature to control and regulate the marriage relation and its incidental property rights." 16 Had this case, which clearly overruled the Spreckels doctrine, been allowed to stand, California would have saved itself a great many headaches. The decision was, however, undone one year later when on rehearing most of the judges reversed their stand, ${ }^{17}$ thereby setting back the development of marital property law for several decades.

In the second Thornton case of 1934 the court refrained from touching the Spreckels rule. From there it was a logical step to hold that a newcomer to California may not be treated differently from an established resident:

If the right of a husband, a citizen of California, as to his separate property, is a vested one and may not be impaired or taken by California law, then to disturb in the same manner the same property right of a citizen of another state, who chances to transfer his domicile to this state, bringing his property with him, is clearly to abridge the privileges and immunities of the citizen. ${ }^{1 \times}$

The court did not consider that by classifying out-of-state-

11. See Armstrong, "Prospective" Application, supra note 4.

12. CAL. Civ. CODE $\$ 16$ la (West 1954), added by Ch. 265, § 1, [1927] Cal. Stats. 484.

13. See, e.g., Jacquemart v. Jacquemart, 125 Cal. App. 2d 122, 269 P.2d 951 (1954). Also see Armstrong, Family Law: Order out of Chaos, 53 CALIF. L. Rev. 121, 132-33 (1965).

14. Boyd v. Oser, 23 Cal, 2d 613, 145 P.2d 312 (1944).

15. In re Thornton's Estate, 19 P.2d 778 (Cal. 1933).

16. Id. at 784 .

17. Estate of Thornton, I Cal. 2d 1, 33 P.2d I (1934).

18. Id. at 5,33 P.2d at 3. The court added two somewhat obscure sentences to the effect that due process was also violated. On these sentences, see Schreter, supra note 1, at 218-22. 
acquired common law marital property as "separate property" under community property concepts California actually did alter property rights and expectations substantially, although it did mention that the property in question would have been subject to the wife's dower rights in Montana. ${ }^{19}$ These rights and others were lost when the property became separate property in California. The extent of the error in equating the two property categories was apparently not realized at the time and was only brought to light by Professor Marsh's detailed study published in 1952.0

After Thornton II there was no breath of fresh air until 1944 when Justice Traynor in a brief concurring opinion in Boyd v. Oser21 expressed the view that the rule against retroactive changes in marital property rules had no sound basis in constitutional law. Inspired by this concurring opinion, Professor Armstrong wrote her powerful, now classic, article entitled "Prospective" Application of Changes in Community Property Control-Rule of Property or Constitutional Necessity? ${ }^{22}$ by which she sounded what came to be the death knell for the Spreckels-Thornton doctrine. ${ }^{23}$ Professor Armstrong convincingly demonstrated that despite the ultimate outcome of the Thornton litigation there is "historical evidence that at least by the early thirties, our supreme court became aware that unsound constitutional doctrine had been relied on" in the community property decisions. ${ }^{24}$ She explains that the court did not change its mind as to the unsoundness of the Spreckels rule between Thornton $I$ and Thornton $I I$, but was unwilling to overrule the case in the litigation before it. ${ }^{25}$ Consequently privileges and immunities ${ }^{26}$ rather than due process considerations became the major basis for the decision. So long as it was "bound by the holding that to limit the right of one spouse by increasing the right of the other .... is the disturbance of a vested right, ' ${ }_{27}$ the court said, it must not discriminate against the newcomer

19. 1 Cal. $2 \mathrm{~d}$ at 3,33 P.2d at 2.

20. H. Marsh, Marital Property in Conflict of Laws (1952). For an earlier reference to the problem, see Leflar, Community Property and Conflict of Laws. 21 CALIF. L. Rev. 22I, 226 (1933). See also Schreter, supra note I, at 206-09, 224-25. Also see Estate of Way, 157 P.2d 46, $49-50$ (Cal. App. 1945) (Justice Peters).

21. 23 Cal. 2d 613, 623, 145 P.2d 312, 318 (1944).

22. Armstrong, "Prospective" Application, supra note 4.

23. See text accompanying notes 50-51 infra.

24. Armstrong, "Prospective" Application, supra nöte 4, at 501.

25. Id. at 502-03. See also Schreter, supra note 1, at 222.

26. See Armstrong "Prospective" Application. supra note 4, at 502-03. The court refers to the fourteenth amendment but apparently had in mind the privileges and immunities clause of article IV. See Schreter, supra note I, at 222-24.

27. 1 Cal. $2 \mathrm{~d}$ at 5,33 P.2d at 3. 
by placing restrictions on his property rights from which the California citizen is immune. ${ }^{28}$

Under these circumstances, it is deplorable that an attempt was not made in the late 1940's or in the 1950's to retest the constitutionality of the general reclassification statute, which was not repealed until $1961 .^{29}$ A third Thornton-type case might well have overruled Thornton $I I$ and put new life into the general conversion law. Although this is past history, one cannot but reflect that such a move, if successful, would have made it unnecessary to invent the "quasi-community property" classification. This new category when superimposed on an already unwieldy and cumbersome community property system $^{30}$ makes the whole scheme one of such extreme complexity that its existence is acceptable only if one keeps constantly in mind that this legislative excursion into a world of superabstraction ${ }^{31}$ was-or seemed to be-dictated by the constitutional doctrine of the early cases.

Immediately after Thornton the Probate Code was amended to assimilate the succession rights of newly arrived spouses to those of established Californians, ${ }^{32}$ on the theory conceded by Thornton ${ }^{33}$ that rights of succession are subject to statutory control free from constitutional limitation. This first step seems to have determined the course the legislature followed from that time on-one of piecemeal, gradual transformation of newcomer property into community property in selected areas. ${ }^{34}$ When it became too cumbersome to refer interminably to property acquired by "either spouse while domiciled elsewhere which would have been community property of the husband and wife had the spouse acquiring the property been domiciled in this State at the time of its acquisition",

28. Id. The court's language is quoted in text accompanying note 18 supra.

29. Ch. 636, [1961] Cal. Stats. 1838. The quasi-community property legislation was enacted by the same statute.

30. Professor Armstrong wrote in 1945: "It is commonly agreed by both bench and bar that our community property law in many respects is cumbersome, complicated and ill-adjusted to our needs." Armstrong, "Prospective" Application. supra note 4 , at 481 .

31. The system has recently been characterized as "a patchwork of laws reminiscent of thc federal lnternal Revenue Code." Kanowitz, Sex-Based Discrimination in American Law II. Law and the Married Woman. 12 Sr. Louls U.L.J. 3, 33 (1967). See also note 70 infra.

32. See 1 Armistrong, supra note 3, at 726-31. See also Justice Peters in Estate of Way, 157 P.2d 46 (C)al. App. 1945).

33. I Cal. 2d at 5, 33 P.2d at 3 (last paragraph of majority opinion; the dissent is based on this theory).

34. See 3 Calif. Law Revision Comm'n Reports, Recommendation and Study Relating to lnter vivos Marital Property Rights in Property acquired While DOMICILED ELSEWHERE 1-6 (1961).

35. See id. 
the "quasi-community property" label was adopted..$^{36}$ The language just quoted makes up the major part of the definition of quasicommunity property of section 140.5 of the Civil Code, added in $1961,{ }^{37}$ with the important addition that it applies expressly to property "heretofore or hereafter acquired."

Among the 1961 amendments was a provision that upon divorce or separate maintenance quasi-community property be divided exactly like community property. ${ }^{38}$ The inequities of the prior law were blatant. In a large number of common law property states separate marital property may be divided by the court at the time of divorce, ${ }^{30}$ whereas a California divorce court only had power to decree a division of community property, and consequently could not touch "separate" marital property acquired out of state.10

This was the first legislative step into the area seemingly blocked off by Thornton II, since it concerned the conversion of newcomer property during the lifetime of the spouses. Thus it was not at all a foregone conclusion that the legislation would be upheld."

When the question came to a court test in Addison v. Addison, the trial and appellate courts promptly held the law unconstitutional ${ }^{12}$ although the district court of appeal made it clear that it considered a reexamination of the constitutional question beyond its province. ${ }^{43}$ The California supreme court speaking through Justice Peters, reversed." Although Justice Peters does not overrule Thornton but attempts to distinguish it, there is no question that his opinion taken in its entirety represents an almost complete break with the past.

The facts of the case were perfectly suited for an all-out test. Mr. and Mrs. Addison were married in Illinois in 1939. They moved to California in 1949 bringing personal property valued at 143,000 dollars, a large part of which apparently would have been community property if acquired in California. Mrs. Addison filed a divorce complaint in February 1961, charging adultery. Thereafter, and before the interlocutory decree was entered, the quasi-community property

36. Ch. 636, [1961] Cal. Stats. 1838.

37. Id. § 2. As Professor Armstrong has pointed out, subsection 140.5(b) contains a serious drafting error. The same is true of CAL. Prob. Cone $\S 201.5(b)$ (West Supp. 1968). Sec I ARMStrong, supra note 3, at 350 (Supp. 1966).

38. Ch. 636, § 4, [1961] Cal. Stats. 1839, amending CAL. CIv. CoDE § 146 (West 1954).

39. See H. Clark, Law of Domestic Relations in the United States 449 (1968).

40. CAL. Civ. Code $\S 146$ (West 1954), as amended, Cal. Civ. Code $\$ 146$ (West Supp. 1968).

41. Cf. 3 Calif. Law Revision Comm'n Reports, supra note 34, at 1-7, 1-8.

42. 40 Cal. Rptr. 330 (1964).

43. Id. at 333.

44. 62 Cal. 2d 558, 399 P.2d 897, 43 Cal. Rptr. 97 (1965). 
legislation went into effect. Without the conversion statute hardly any property could have been awarded to Mrs. Addison since most of her husband's accumulations were traceable to property acquired in lllinois, which, as separate property under California law, would not have been subject to the court's power of division upon divorce.

Justice Peters laid his groundwork carefully and on a broad base. He referred to the "sociological problem" to which the legislation addressed itself and to the continuing difficulty California had experienced in solving it because of prior court decisions; ${ }^{45}$ he stated that "California's attempts to apply community property concepts to the foreign, and radically different (in hypothesis) common-law theory of matrimonial rights" were the source of the problem;"46 he described the solution attempted by the 1917 amendment to Civil Code section 164, which was unsuccessful, and the Probate Code amendment, which was upheld. After referring to the holding in Thornton II, Justice Peters wrote:

The underlying rationale of the majority was the same in Thornton as it had been since Spreckels v. Spreckels [citation], which established, by a concession of counsel, that changes in the community property system which affected "vested interests" could not constitutionally be applied retroactively but must be limited to prospective application..$^{47}$

With the ground thus prepared, the Justice began his assault on the traditional theory. He quoted Justice Traynor's concurring opinion in Boyd v. Oser, which rejected the prohibition of retroactive community property changes; referred to several major scholarly writings which condemn the old doctrine; and stated that "the correctness of the rule of Thornton is open to challenge." 48 At this point the Justice interrupted his thrust by pointing out that Thornton could be distinguished since the statute under consideration made "no attempt to alter property rights merely upon crossing the boundary into California," but applied "only if a divorce or separate maintenance action is filed here after the parties have become domiciled in California.",49 But he quickly returned for his major blow:

It cannot be successfully argued that the quasi-community property legislation is unconstitutional because of a violation of the due process

\footnotetext{
45. Id. at 562,399 P.2d at 899,43 Cal. Rptr. at 99 .

46. Id. at $562-63,399$ P.2d at 899,43 Cal. Rptr. at 99.

47. Id. at 564-65, 399 P.2d at 901, 43 Cal. Rptr. at 101.

48. Id. at 565-66, 399 P.2d at 901, 43 Cal. Rptr. at 101.

49. Id. at 566, 399 P.2d at 902, 43 Cal. Rptr. at 102.
} 
clause of the federal Constitution. Morton [Mr. Addison] has not been deprived of a vested right without due process. As Professor Armstrong has correctly pointed out in her article, supra: "Vested rights, of course may be impaired 'with due process of law' under many circumstances. The state's inherent sovereign power includes the so called 'police power' right to interfere with vested property rights whenever reasonably necessary to the protection of the health, safety, morals, and general wellbeing of the people. The annals of constitutional law are replete with decisions approving, as constitutionally proper, the impairing of, and even the complete confiscation of, property rights when compelling public interest justified it.

"The constitutional question, on principle, therefore, would seem to be, not whether a vested right is impaired by a marital property law change, but whether such a change reasonably could be believed to be sufficiently necessary to the public welfare as to justify the impairment." '50

This paragraph contains the crux and core of the entire opinion. It expresses the modern view with respect to the protection of property interests and rejects the exaggeration of earlier days which guaranteed absolute, immutable, "vested" rights, immune from any restriction in the public interest. On the basis of this paragraph the Justice found that the state has a legitimate interest in and power to regulate the division of marital property upon dissolution of a marriage, and concluded that the quasi-community property amendments involved did not contravene the federal or state due process clauses.51

Justice Peters did not mention Spreckels again in this connection nor did he speak of retroactive application of the 1961 law except to say that it was sufficient that the law was in effect at the time of the judgment. ${ }^{52}$ Nevertheless, the implications are clear. The decision holds that the I96I statute applies to marital property brought to California in 1949 and owned by the husband as his separate property

50. Id., citing Armstrong, "Prospective" Application, supra note 4, at 495-96 (emphasis added).

51. Id. at 567, 399 P.2d at 902-03, 43 Cal. Rptr. 102-03. Justice Peters uses language in this passage which almost seems to limit his conclusions to "iinocent" parties who "would otherwise be left unprotected." This is surprising in view of the Justice's modern approach to marriage dissolution, manifested, for example, in Hull v. Superior Court, 54 Cal. 2d 139, 352 P.2d 161, 5 Cal. Rptr. I (1960). See text accompanying notes $145-48$ infra. For other commenis on this passage, see Gardner, supra note I, at 260 n.54; Lay, supra note I, at 309-10.

52. $62 \mathrm{Cal} .2 \mathrm{~d}$ at $569,399 \mathrm{P} .2 \mathrm{~d}$ at 904,43 Cal. Rptr. at 104. 
under California law for 12 years..$^{53}$ it permits the retroactive alteration of his property rights by subjecting the property to division upon divorce. It would be difficult to find a more decisive abrogation of the Spreckels principle. Justice Peters clearly overruled the Spreckles case, whether he did so expressly or not.54

In the concluding part of the opinion Justice Peters determined that the statute violates neither one of the privileges and immunities clauses. As to section 2 of article IV of the United States Constitution, he concluded that "discrimination, if there be such, is reasonable" 55 because the former nondomiciliary wife who lost the protection afforded her by lllinois "is thus in need of protection from California." ${ }^{56}$ The second Thornton court, if it had been able to free itself from the Spreckles rule, would have reached the same result in a different manner: After a holding that the court would no longer apply the vested rights doctrine the privileges and immunities argument automatically disappears. Newcomer and native are treated alike; there is no discrimination; both are subject to subsequent reasonable regulation in the public interest..$^{57}$

The husband in the Addison case had also claimed a violation of the privileges and immunities clause of the fourteenth amendment, citing Thornton II. Justice Peters concluded that the statute does not violate this provision. But he employed unusual reasoning which is difficult to follow. He attempted to distinguish Thornton $I I$ and thereby narrowed the breadth of his otherwise far-reaching opinion. He explained that the clause relates to the privileges of a United States citizen which arise from the United States Constitution and from federal laws and continued:

Aside from the due process clause, already held not to be applicable, Thornton may be read as holding that the legislation there in question impinged upon the right of a citizen of the United States to maintain a domicile in any state of his choosing without the loss of valuable property rights. ${ }^{j *}$

53. This holding goes further than Thornton 1 . The Thornton cases involved property that had been brought to California in 1919, two years, after the 1917 amendment to section 164 of the Civil Code. Thornton $I$ in a strong dictum declared that the conversion statute could not constitutionally apply to property taken to California before its effective date, citıng Estate of Drishaus, 199 Cal. 369, 249 P. 515 (1926). 19 P.2d at 782. For a most interesting comment on Drishaus, see Comment, 15 CALIF. L. Rev. 399 (1927). The writer of this Comment, signed "R. E. P." who has been identified as Justice Peters by Gardner, supra note 1, at $259 \mathrm{n.47}$, seems to agree with the result in Thornton $I$ and was cited as authority in that case. 19 P.2d at 783 .

54. Gardner, supra note 1 , at $269,279$.

55. 62 Cal. 2d at 569, 399 P.2d at 904, 43 Cal. Rptr. at 104 (emphasis added).

56. Id.

57. See text accompanying notes 24-28 supra.

58. 62 Cal. $2 d$ at 568, 399 P.2d at 903, 43 Cal. Rptr. at 103. 
This, he said, the statute does not do:

Unlike the legislation in Thornton, the quasi-community property legislation does not cause a loss of valuable rights through change of domicile. The concept is applicable only in case of a decree of divorce or separate maintenance..$^{59}$

And he referred back to an earlier passage where he stated,

the legislation under discussion, unlike old section 164, makes no attempt to alter property rights merely upon crossing the boundary into California. ${ }^{60}$

1 have searched constitutional law, the Thornton II case (from which the Justice says he derives his thesis), and the law review comment which is his only other reference, ${ }^{61}$ and have been unable to find any authority which suggests that there is a federal right of the type the Justice suggests. The writer of the comment cited by Justice Peters after some speculation as to what the Thornton court might have had in mind when it referred to the fourteenth amendment privileges and immunities clause, ${ }^{62}$ finally concluded that the Thornton court "really is concerned with the discriminatory aspects" of the law which it "might hold void under Article $1 \mathrm{~V}$, section 2, of the United States Constitution." 63 That there was an erroneous reference to the fourteenth amendment instead of article IV in the Thornton opinion seems clear. ${ }^{64}$ No decision of the United States Supreme Court or other federal court decision has been found supporting the Justice's position on this point. ${ }^{65}$

59. Id.

60. Id. at 566,399 P.2d at 902,43 Cal. Rptr. at 102. In this connection the Justice quotes a passage from Thornton II, I Cal. $2 \mathrm{~d}$ at 5, 33 P.2d at 3, quoted at note 18 supra, which seems to relate to article IV of the Constitution. See note 26 supra.

61. Comment, 8 S. Cal. L. Rev. 221, 225 (1935).

62. "The modes of thought by which the court [in Thornton II] arrived at the use of the privileges and immunities clause of the Fourteenth Amendinent as the primary basis for declaring the section void remain invisible in the decision . . . However, one plausible extension in the substantive law remains, which may be signifieant in the Thornton case. The very first sentence in the Fourteenth Amendment expressly makes every citizen of the United States a citizen of the State wherein he resides. It has been suggested that this privilege of being also a citizen of a State is a privilege of federal citizenship . . . Accordingly, if Civil Code, Seetion 164, places a restriction on that right by requiring the husband to give up property rights in order to become a citizen of California, it might be argued that it would violate this constitutional guaranty. Still, such an interpretation would extend the clause beyond the protection of the right to become a citizen, as such, to a more dubious matter of protecting property rights, which are amply protected by other constitutional guaranties." Id. at 224-25.

63. Id. at 225-26.

64. See note 26 supra.

65. See legislative Reference Service, Library of Congress, The Constitution of the UNITED States, ANALYSIS AND INTERPRETATION 1075-82 (1964); Schreter, supra note I, 
As far as Thornton is concerned, the Justice himself said that "the underlying rationale of the majority was the same in Thornton as it had been since Spreckels v. Spreckels." 66 Professor Kay amplifies this thought when she states that Thornton remains "only so long as Spreckels endurcs."67 However, Justice Peters did not overrule Thornton even though he successfully removed the reasons upon which it was built. By inventing a "boundary crossing" right and attributing it to Thornton, he gave this case a shadow lease on life. ${ }^{68}$

Despite this one problem area, Justice Peters' opinion in Addison v. Addison is of tremendous significance for established California spouses and newcomers alike. It resolved two burning questions by holding, first, that existing marital property rights may be altered by appropriate legislation, and, second, that newcomer marital property may be transformed into community property for certain purposes, This opens up broad vistas for legislative reform. While we may perhaps need one more pronouncement of the California supreme court which broadens the holding in Addison, the long-desired overhaul of the community property system seems to have moved so close to the realm of possibility that preparation for such an undertaking could begin immediately. Among other changes, "quasi-community property" could be eliminated so that there would be "one single marital property law for all Californians." 69 What

at 223. It is perplexing that Justice Peters seems to disagree with "R.E.P." (see note 53 supra) who had suggested that the rights of a newcomer "in the property that he brings with him, from the viewpoint of the California law, date from the moment that he crosses the California boundary line." "R. E. P." saw no constitutional problem in making a reclassification right at the border. Comment, 15 Calif. L. Rev. 399, 407 (1927). Cf. the comment on "R. E. P."'s "interesting and ingenious argument" by Professor Leflar who would agree with the argument once the "vested rights" doctrine of Spreckels is removed. Leflar, supra note 20, at 237 \& n.119, 238.

66. This passage is quoted in full at note 47 supra.

67. Schreter, supra note 1, at 224. Professor Kay states further:

So long as the Spreckles doctrine remains imbedded in California law, 1 do not see any effective answer to the qualified and limited basis for sustaining the Thornton result found in the privileges and immunities clause of article IV. If it is recognized, however, that the federal constitution contains no obstacle to the abolition of the Spreckels doctrine, then there is equally no obstacle to the destruction of the Thornton result. These two impediments to the reform of community property law in California may be ended simultaneously in a proper case.

Id. at 225-26. Professor Armstrong seems to agree. See Armstrong, "Prospective" Application, supra note 4 , at $501-03$.

68. For possible problems created by this theory, see Gardner, supra note 1, at 269-80.

69. Schreter, supra note 1 , at 244 . See also id. at 226. 
Professor Armstrong fervently hoped for in 1945, may now be close to realization:

The marital unit is still the foundation stone of society. The firmness of that foundation is of primary importance. Economic aspects of the marital partnership inevitably affect it. A marital property system that is uncomplicated, understandable, and as nearly as possible in tune with contemporary conviction is of constant concern to us all. A rejection of the unfortunate constitutional doctrine which has found its way into community property decisions will not bring us this desired property law. It will, however, unshackle the legislature and thus put the system within our statutory reach.0

REVIVAL OF COMMUNITY PROPERTY

In two interesting cases Justice Peters deals with the "revival" of community property after the death of both spouses, which may occur under California succession law.71 Under section 228 of the Probate Code, property which was at one time community property of the decedent and a predeceased spouse, may descend to the relatives of the spouse who died first and the relatives of the decedent in equal shares. This may happen if the decedent leaves neither issue nor a second spouse and if the community property "belonged or went to the decedent by virtue of its community character on the death of such [previously deceased] $]_{-}$svouse."72

Estate of Simmons ${ }^{73}$ involved the estate of a widow whose previously deceased husband had willed one-half of the community property to nieces and nephews on his side of the family. His widow died without making a testamentary disposition of her half of the community and left neither spouse nor issue. The community property consisted of a parcel of real property. The problem was whether the

70. Armstrong, "Prospective" Application, supra note 4, at 505. See also Knutson, California Community Property Laws: A Plea for Legislative Study and Reform, 39 S. CAL. L. REv. 240, 266 (1966):

There is no need, in my judgment, for such an unwieldy and complex system. There is no reason for the inconsistent and inequitable results sometimes achieved by its application. The inordinate amount of litigation spawned by the rules as they have developed would seem to be reason enough for legislative simplification. If we are to have a clean, simple and fair community property system, consistent with our other property, family and commercial goals, we must go to the root of the difficulty, which is the underlying classifications and assumptions. In short, the whole system must be examined and reformed if there is to be any effective reform. 745-70.

71. Cal. Prob. Code $\S 228$ (West 1956). See generally 1 ArMStrong, supra note 3, at 1956).

72. And under circumstances not here relevant. CAL. ProB. CODE $\$ 228$ (West

73. 64 Cal. 2d 217, 411 P.2d 97, 49 Cal. Rptr. 369 (1966). 
husband's relatives who had already received half of the property under the husband's will could again share in the remaining half and end up with three-quarters of the land. Justice Peters concluded that there was no escape from the statutory language which dictated such a distribution:

There is no language in section 228 of the Probate Code conditioning its application upon the predeceased spouse leaving to the other spouse community property which was subject to the former's testamentary disposition. Although the general purpose of the statute, which is to establish equality between the blood relatives of each of the spouses, might in some cases be served by such a condition, this is not true in every case. This is a legislative problem. ... .

... [T] The reference in the section of community property which "belonged or went" to the decedent by virtue of its community character demonstrates that the section is applicable to all former community property left by the decedent . . . .

The Justice was correct in concluding that little would be gained by a judicial attempt to read piecemeal exceptions into a statute that is really in need of overall legislative reconsideration.

In Estate of Adams ${ }^{75}$ Justice Peters encountered the problem of tracing the former community property beyond the death of the first spouse to the estate of the second, which is involved in much of the litigation under section 228 (and section 229) of the Probate Code. As the Justice stated:

There are many anomalies presented in interpreting and applying sections 228 and 229 of the Probate Code. (See Ferrier, Rules of Descent under Probate Code Sections 228 and 229; 25 Cal. L. Rev. 261.) Not the least of these is that, although upon the death of the wife, intestate, where the husband acquires all of the community property, he becomes the absolute owner of it, so that there no longer is community property in the true sense, nevertheless for purposes of succession under section 228 of the Probate Code, "the statutory provisions determining what is community property as construed by our decisions remain in force and applicable throughout the life of the surviving spouse, as to all property constituting community property of the spouses at the time of the death of the predeceased spouse." ${ }^{\text {"it }}$

The case illustrates the magnitude of the tracing problem. The Justice succeeded in introducing some clarity into the matter by distinguishing between the two periods of time the tracing process

74. Id. at 221-22, $411 \mathrm{P} .2 \mathrm{~d}$ at $100,49 \mathrm{Cal}$. Rptr. at 372.

75. 132 Cal. App. 2d 190, 292 P.2d 190 (1955).

76. Id. at 203,282 P.2d at $198-99$. 
must cover - the period when the couple lived together as husband and wife and the period from the death of the first spouse to the death of the second." As to the first period, Justice Peters says, the heirs of the predeceased spouse are aided by the presumption that property acquired or in possession during the marriage was community property. But as to the second period "such heirs now find the presumptions reversed. Now the presumption is, that the property in the estate of the surviving spouse is the separate property of the surviving spouse ...."78 The Justice found in the case before him that because of the onus of the latter presumption, the heirs of the predeceased spouse had not proven that any property in the estate of the surviving spouse was traceable to former community property.

As the Justice intimated, both of these cases raise questions as to the desirability of retaining the legislative scheme contained in sections 228 to 230 of the Probate Code, at least in its present form. The article by Ferrier ${ }^{79}$ referred to by Justice Peters shows that the "ancestral property" idea embodied in these sections apparently developed more or less accidentally out of a statute originally designed as a "mere last resort before escheat." the present scheme does not even avoid escheats in some of the situations in which there are surviving relatives. ${ }^{81}$

77. Id. at 197,282 P.2d at 195.

78. Id. at 204, 282 P.2d at 199.

79. Ferrier, Rules of Descent Under Probate Code Sections 228 and 229, and Proposed Amendments, 25 CALIF. L. Rev 261 (1937).

80. Id. at $262,280$.

81. See Cal. Prob. Code $\S \S 228-30$ (West 1956). See, e.g., State v. Broderson, 247 Cal. App. 2d 797, 56 Cal. Rptr. 58 (1967); Estate of Blume, 24 I Cal. App. 2d 496, 50 Cal. Rptr. 622 (1966); Estate of Roberts, 85 Cal. App. 2d 609, 194 P.2d 28 (1948).

Among other noteworthy cases authored by Justice Peters in the community property field several deserve special mention. Estate of Walsh, 66 Cal. App. 2d 704, 152 P.2d 750 (1944), held that gifts of jewelry from husband to wife at Christmas and on anniversaries were eommunity property rather than separate property of the wife. This led Professor Armstrong to remark that wives better insist on written gift tags specifying the article to be their "separate estate." 1 Armstrong, supra note 3, at 505. Christiana v. Rose, 100 Cal. App. 2d 46, 222 P.2d 891 (1950), held damages recovered for the wrongful death of a child in the eustody of her mother separated from her husband to be separate property of the wife. Also see Hogevoll v. Hogevoll, 59 Cal. App. 2d 188, 138 P.2d 693 (1943), which held that money borrowed by the wife and property acquired with it, while the wife is living separate and apart from her husband, is her separate property. And in Estate of Cushing, 113 Cal. App. 2d 319, 248 P.2d 482 (1952), Justice Peters clarified the law as to the effeet of federal estate taxes at the death of a husband upon the computation of the wife's half of the community estatc. The case held that federal estate taxes on pre-1927 community property, but not on community property acquired after 1927, are to be deducted from the entire community estate before dividing the estate into two halves. The decision was followed in Estate of Resler, 43 Cal. 2d 726, 278 P.2d I (1954). 


\section{INTRAFAMILY TORTS}

With two blows delivered the same day, Justice Peters overruled Peters v. Peters ${ }^{32}$ and struck down California's interspousal immunity doctrine. Self $v$. Self ${ }^{\beta 3}$ was a wife's damage suit for assault and battery against her husband, and Klein $v$. Klein ${ }^{84}$ involved a husband's negligence when his wife fell and broke her leg on the slippery deck of his pleasure boat. In the first case Justice Peters declared, "at least for an intentional tort, one spouse may maintain an action against the other in California," 85 and immediately thereafter announced in the second case, "the Iogical and legal reasons ... that caused us to abandon the old rule as to intentional torts apply with equal force to negligent torts." 86

Since the ancient doctrine of legal indentity between husband and wife and the social order upon which it was based no longer exists, Justice Peters reasoned, there is no justification for a retention of the immunity rule. With precision and dispatch he also disposed of the more recent arguments favoring the continuation of the immunity. First, peace and harmony in the home are no more disturbed by a personal injury action than by a tort action involving property, which has long been permitted, ${ }^{87}$ moreover, Justice Peters stated, harmony seldom prevails in a home in which court action is contemplated. ${ }^{88}$ Second, "The argument about inundating the courts with trifling suits is paIpably unsound. We have not been informed that such result has followed in any of the 18 states that have repudiated the old rule." 99 Third, the danger of fraud and collusion when insurance is involved-a possibility which "exists to some degree in all cases"-is no. ground to deny the action. "It would be a sad commentary on the law if we were to admit that the judicial processes are so ineffective

82. 156 Cal. 32, 103 P. 219 (1909).

83. 58 Cal. 2d 683, 376 P.2d 65, 26 Cal. Rptr. 97 (1962).

84. 58 Cal. 2d 692, 376 P.2d 70, 26 Cal. Rptr. 102 (1962). Justices Schauer and McComb dissented in this case.

85. 58 Cal. $2 \mathrm{~d}$ at 691,376 P. $2 \mathrm{~d}$ at 70,26 Cal. Rptr. at 102.

86. 58 Cal. 2d at 694, 376 P.2d at 72, 26 Cal. Rptr. at 104.

87. In Self $v$. Self, Justice Peters said "[I]f the husband breaks his contract with his wife in reference to property, or breaks the gate to her house, she could sue him. But, under the Peters case, she cannot sue him if he breaks her arm." 58 Cal. $2 \mathrm{~d}$ at 690 n.3, 376 P.2d at 69 n.3, 26 Cal. Rptr. at 101 n.3.

88. Id. at 685,376 P. $2 \mathrm{~d}$ at 66,26 Cal. Rptr. at 98, quoting Dean Prosser's famous sentence about the "state of peace and harmony left to be disturbed" after a husband has beaten his wife.

89. Klein v. Klein, 58 Cal. 2d 692, 694, 376 P.2d 70, 72, 26 Cal. Rptr. 102, 104 (1962). 
that we must deny relief to a person otherwise entitled simply because in some future case a litigant may be guilty of fraud or collusion. Once that concept were accepted, then all causes of action should be abolished. Our legal system is not that ineffectual." 90 As an added reason for his conclusions Justice Peters pointed to the legislative amendment of 1957 which removed the prior impediment in the rule that whatever one spouse recovered from the other in a personal tort action belonged to both and could be freely disposed of by the husband under his community management powers. ${ }^{91}$

Since the two decisions were rendered, the legislature has recognized the general principle of these cases. Section 163.5 of the Civil Code provides:

All money or other property paid by or on behalf of a married person to his spouse in satisfaction of a judgment for damages for personal injuries to the spouse or pursuant to an agreement for the settlement or compromise of a claim for such damages is the separate property of the injured spouse..$^{92}$

This section implies that husband and wife are liable to each other for personal injuries inflicted but does not state the extent of this liability.

With the Self and Klein decisions California intrafamily tort law has, in the words of Professor Armstrong, "caught up with the 20th century." California thus joined the ranks of the sizeable minority of states which have abolished husband-wife immunity for both intentional and negligent torts. ${ }^{.4}$ Indeed, California may now have taken the lead. Since much of the litigation in other states has involved negligence or recklessness in automobile injury litigation, ${ }^{95}$

90. Id. at 696,376 P.2d at 73, 26 Cal. Rptr. at 105. Justice Schauer disagrees on this point. While he would permit personal tort actions between husband and wife in case of intentional injuries, he sees a real danger of perjury and collusion in negligence cases. He would leave this matter to the legislature to regulate in all its ramifications, as New York has done. Id. at 696, 376 P.2d at 73, 26 Cal. Rptr. at 105 (dissenting opinion). See also Rheinstein, Challenge and Response in Fanily Law 17 VAND. L. Rev. 239, 246-50 (1963), where Professor Rheinstein expresses strong disagreement with the trend toward permitting personal injury actions between husband and wife.

91. Self v. Self, 58 Cal. 2d 683, 690-91, 376 P.2d 65, 69-70, 26 Cal. Rptr. 97, 101-02 (1962). This result of the 1957 amendment, ch. 2334, § I, [1957] Cal. Stats. 4065, adding CAL. Civ. Code $\S 163.5$ (West Supp. 1968), was-not affected by the 1968 amendment to this section. See text at note 92 infra. See also the 1968 amendment to CAL. Civ. Code $\$ 17$ la (West Supp. 1968), ch. 457, $\$ 6$, [1968] Cal. Stats. 1079, which removes another problem in this area. See 2 ARMSTRONG, supra note 3 , at 1468 .

92. Cal. Civ. Code § 163.5 (West Supp. 1968).

93. 2 ARMSTRONG, supra note 3, at 460 (Supp. 1966). 254.

94. See W. Prosser, Law of Torts 884-85 (3d ed. 1964); H. Clark, supra note 39, at

95. See authorities cited note 94 supra. 
and since automobile personal injury actions may be sui generis, these states may still have retained interspousal immunity in other areas of the law. However, Justice Peters' language in Self and Klein, neither of which was an automobile case, seems so broad as to sweep away the old rule in its entirety in California.

The next development is likely to be the abandonment of the parent-child immunity for negligent torts. Emery v. Emery ${ }^{96}$ has already abrogated this immunity for wilfully inflicted injuries "beyond the limits of reasonable parental discipline." ${ }_{97}$ From "wilful misconduct" under the guest statute in Emery to liability for negligence-at least for automobile negligence-is not a big step. Although very few states have gone so far as to abolish immunity for negligence in parent-child actions, ${ }^{98}$ California may well be among the first states to do so in view of its leadership in expanding tort liability in other areas. Moreover, if Justice Peters' approach to tort liability expressed in Klein and Self is followed, it would seem that the burden of persuasion is on the party relying on the immunity rather than on the one seeking the overruling of old precedents. In Klein the Justice started out from the very general premise that

It is . . . fundamental in the law of torts that any person proximately injured by the act of another, whether that act be wilful or negligent, should, in the absence of statute or compelling reason of public policy, be compensated.9

There is no statute incorporating the parental immunity doctrine, and most of the policy reasons in its favor are identical with those advanced for interspousal immunity that have already been rejected by Self, Klein, and Emery. In child-parent litigation, however, there is the additional factor discussed by Justice Traynor in Emery that law suits might interfere with a parent's "wide discretion in the performance of his parental functions.' "100

This consideration suggests that while there are no compelling

96. 45 Cal. $2 \mathrm{~d} 42 \mathrm{l}, 289$ P.2d 218 (1955).

97. Id. at 430,289 P.2d at 224 .

98. See H. CLARK, supra note 39, at 258-60; Comment, Automobile Negligence Cases and the Parental Immunity Doctrine, 5 WILlamette L.J. 140 (1968): Comment, Child v. Parent: Erosion of the Imminity Rule, 19 HAST. L.J. 201 (1967). See also Gelbman v. Gelbman, 37 U.S.L.W. 2412 (N.Y. Jan. 9, 1969), which abandoned the parent-child immunity.

99. 58 Cal. $2 \mathrm{~d}$ at $694-95,376$ P.2d at 72, 26 Cal. Rptr. at 104. See also Self v. Self, 58 Cal. 2d 683, 689, 376 P.2d 65, 69, 26 Cal. Rptr. 97, 101 (1962). Compare CAL. CIv. CODE $\$ \$ 1708,1714$ (West 1954). See also the maxim "for every wrong there is a remedy", CAL. CIV. CODE $\$ 3523$ (West 1954), which Justice Traynor refers to as "the general principle of liability" in Emery v. Emery, 45 Cal. 2d 421, 430, 289 P.2d 218, 224 (1955).

100. 45 Cal. $2 \mathrm{~d}$ at 430,289 P.2d at 224. 
policy reasons to retain the child-parent immunity for negligence in traffic accident cases and similar situations, there may be good grounds for limiting liability in other areas. As the Supreme Court of Wisconsin stated in Goller v. White,

After a careful review of the arguments for and against the parentalimmunity rule in negligence cases, we are of the opinion that it ought to be abrogated except in these two situations: (1) where the alleged negligent act involves an exercise of parental authority over the child; and (2) where the alleged negligent act involves an exercise of ordinary parental discretion with respect to the provision of food, clothing, housing, medical and dental services, and other care. Accordingly the rule is abolished in personal injury actions subject to these noted exceptions..$^{101}$

In this twilight zone between family and tort law, one cannot escape the fact that the family relationship in one way or another does enter into the legal policy considerations and keeps us from treating intrafamily torts exactly like torts among strangers.

In the first place, the danger of fraudulent or trumped up claims is not as minimal as Justice Peters would have us believe, ${ }^{102}$ but is "in fact considerably increased by the family relation," as Dean Prosser remarks. ${ }^{103}$ This may be true particularly in the vast area of accidents that occur in the seclusion of the home without outside witnesses. But it is not here suggested that the immunity rule be retained for this reason. The fraud affects primarily the insurance companies and they are normally capable of protecting their own interests..$^{104}$ The ultimate burden of mounting insurance premiums is, however, borne by the public and may, if the floodgates of home accident cases are opened wide by the courts, become so excessive as to require some legislative or judicial remedy.

Second, many familes are not insured against the particular risk either because insurance is not normally available for the type of risk-as for example for intentional torts-or because they cannot afford insurance. It is often said that in the absence of insurance intrafamily tort litigation will not occur unless domestic tranquillity has already been disrupted, and in that case there can be no objection to bringing suit. The matter is not that simple. "Family harmony" is not a state or condition which is here one day and gone the next.

101. 20 Wis. $2 \mathrm{~d} \mathrm{402,} \mathrm{413,} 122$ N.W.2d 193, 198 (1963).

102. Klein v. Klein, 58 Cal. 2d 692, 695, 696, 376 P.2d 70, 72, 73, 26 Cal. Rptr. 102, 104, 105 (1962).

103. W. Prosser, supra note 94 , at 889.

104. H. ClaRK, supra note 39, at 253. 
There are fluctuations in husband-wife relationships and (perhaps more so) in parent-child relations, and there are many families where the equilibrium in either or both respects is a delicate one at some periods of time. Once tort suits are freely available within the family, there is the distinct possibility that they may be resorted to as "spite" actions or as a means of getting even on some point of disagreement, such as an argument over family finances. An uninsured spouse or parent may react so bitterly in such a situation that a break-up of the marriage or disinheritance of the child may ensue. This may be an extreme case; however, once the immunity is abolished there is little likelihood that uninsured spouses or parents will be spared litigation which may create family strife and tension not previously in existence. It seems then that the much-maligned "family harmony" theory, which is, of course, ill used when employed as a shield by an insurer, does have a legitimate place in the sun.

Third, without considering domestic peace and harmony, there is the question whether there is not a private sphere of ordinary day to day living within the family into which the law should not under ordinary circumstances intrude. The Wisconsin supreme court in Goller $v$. White, quoted above, ${ }^{105}$ seems to have had such a thought in mind, and the lllinois case of Schenk $v$. Schenk expresses the idea as follows:

[T] here are no impelling reasons for eroding or emasculating the family immunity rule for conduct of either parent or child arising out of the family relationship and directly connected with the family purposes and objectives in those cases where it may be said that the carelessness, inadvertence or negligence is but the product of the hazards incident to inter-family living and common to every family. In such instances the immunity doctrine is neither unjust, unreasonable nor without a sound and solid foundation. To hold otherwise is to inject into the courts a judicial supervision over everyday family conduct of parent and child, and invite endless litigation over what is or is not ordinary negligence in the operation of a household. The assumption of the role of paterfamilias by either the courts or State, except under most compelling circumstances, is foreign to our way of life..$^{106}$

This statement is relevant, of course, both to filial and spousal actions. Some of the suits brought might be trivial claims for minor annoyances (such as an action for nagging) which Dean Prosser

105. Text accompanying note 101 supra.

106. Schenk v. Schenk, 100 111. App. 2d 199, 206, 241 N.E.2d 12, i5 (1968). The court held that there was no immunity in an automobile negligence case. 
suggests be taken care of by finding consent, or at least assumption of risk, to "all ordinary frictions of wedlock." 10 i The British have dealt with this matter by legislation enacted in 1962 which authorizes courts to terminate tort actions between spouses "if it appears that no substantial benefit would accrue to either party from the continuation of the proceedings." 108 Also, there is the possibility that after separation or divorce husband or wife may "remember" past "injuries" to augment a divorce settlement, or that during an existing and continuing marriage suit may be brought for some injury, real or feigned, for the purpose of enlarging the separate estate of the less affluent spouse. ${ }^{109}$

The problems in intrafamily suits have been pointed out not to raise objections to the abandonment of the intrafamily immunity doctrine but to suggest that a complete, all-out repudiation of the doctrine may be neither necessary nor desirable.

\section{IV \\ LOSS OF CONSORTIUM}

It is curious that the question of recovery for loss of consortium first reached the California supreme court squarely in connection with a wife's action for the loss of her husband's companionship, aid, and society. Her claim was denied in Deshotel v. Atchison, Topeka \& Santa Fe Railway.110 Two years later a husband who attempted to recover for the loss of his wife's consortium was also turned down in West v. City of San Diego,"1" mainly because the wife has no corresponding claim in California.

Justice Peters in a spirited and forceful dissent in West disagreed with his brethren:

The majority . . . hold that, in this state, a husband has no cause of action for the negligent interference with those noneconomic aspects of marriage usually included within the term "consortium." Stated another way, the majority hold that a husband, in this state is not entitled to recover on his own behalf for a negligent injury to his wife

107. W. ProsSER, supra note 94 , at 883 .

108. Law Reform (Husband and Wife) Act, $10 \& 11$ Eliz. 2, ch. 48 (1962).

109. Another type of litigation encouraged by the abolition of the immunity is exemplified by Mroczynski v. McGrath, 34 11l. 2d 451, 216 N.E.2d 137 (1966), in which damages were sought by a son from his father's estate to compensate him for the the destruction of the faunily unit resulting in divorce, the denial of unstinted financial aid, and the denial of a normal home, parental affection, and the guidance of a normal father-child relationship.

110. 50 Cal. 2d 664, 328 P.2d 449 (1958).

111. 54 Cal. 2d 469, 353 P.2d 929. 6 Cal. Rptr. 289 (1960). 
that results in depriving him of his privilege of sexual intercourse with his wife, of the possibility of becoming a father, and of the right to the society, care and comfort of his wife. This holding is unrealistic and unsound.

. . . [T]he majority state that because the wife had no such right at common law it "would be extremely inequitable" to grant the right to the husband. This solicitude for symmetry in the law may be laudable but it carries little weight against a settled rule of the common law ... . The point does not have to be labored that the law is not necessarily logical nor symmetrical . . . . Moreover, it can be argued with what I submit is sounder logic, that, if symmetry is to be secured, it should be secured by holding that the wife as well as the husband is entitled to maintain such an action. ${ }^{112}$

Thus Justice Peters advocates a right of both husband and wife to recover for loss of consortium while the majority holds that neither one of them has such a right. As far as equality between the spouses is concerned, the two views are equally acceptable. ${ }^{113}$ From the standpoint of practicality and simplicity the majority view has a great deal to commend itself since it avoids problems concerning res judicata, joinder of parties, and possible double recovery. ${ }^{14}$ Also, if one considers the unavoidably arbitrary nature of the jury's translation of the various items of non-monetary damages (such as damages for pain and suffering $)^{115}$ into dollars and cents, the omission of this one item does not seem serious.

Perhaps more important is the question whether the deprivation of companionship, sexual partnership, and all the other ingredients of "consortium" suffered by one spouse does not correspond to an equal loss experienced by the other spouse through the impairment of his or her ability to give and receive these benefits. It seems to me idle to argue whether these are two losses or one; it certainly is a mutual and joint (and perhaps also several) injury which could legitimately be asserted by one spouse alone in one unitary action. ${ }^{116}$ If there is

112. Id. at 482, 484, 353 P.2d at 937, 938, 6 Cal. Rptr. at 297, 298.

113. Eight other states agree with the majority in West and Deshotel. Fourteen states (as of 1966) recognize a right of both spouses to recover for loss of consortium. H. CLARK, supra note 39 , at $273-75$.

114. See id. at 276-77; Annot., 12 A.L.R.3d 933 (1967).

115. On the problem of measuring these damages, see, e.g., Beagle v. Vasold, $65 \mathrm{Cal} .2 \mathrm{~d}$ 166, 417 P.2d 673, 53 Cal. Rptr. 129 (1966).

116. Justice Peters himself, for practical reasons, has on at least two occasions favored the inclusion in the primary personal injury action itself of a claim that could or should have been asserted by another family member. See Louie v. Hagstrom's Food Stores, 81 Cal. App. 2d 601, 184 P.2d 708 (1947); Bauman v. City and County of San Francisco, 42 Cal. App. 2d 144, 108 P.2d 989 (1940). Since 1968 tort recoveries of husband or wife from third persons are again 
danger that such an approach might reduce the size of verdicts, ${ }^{117}$ there is no reason why the extent and mutuality of the loss could not be spelled out in the instructions. That the primarily injured party has a right to be compensated for such non-economic losses which in connection with his spouse are termed "loss of consortium" seems to be conceded by the supreme court in Deshotel where the majority stated:

A judgment obtained by a husband after he is injured by a third person might include compensation for any impairment of his ability to participate in a normal married life, and, if his wife is allowed redress for loss of consortium in a separate action, there would be danger of double recovery."18

This is a recognition of the fact that the loss is compensable, which is more important than the question of who can claim it.

As the law now stands in California, the husband still has a separate claim for loss of the services of his wife."1" The wife has no such claim. This old relic of medieval law should be removed ${ }^{120}$ unless the supreme court could, and would in a proper case, recognize a corresponding right of the wife to recover for the loss of her husband's services. It would, however, be much more desirable if, as the court explicitly suggested in the Deshotel case, the legislature would clarify this whole area of the law and bring it up to date. ${ }^{.21}$

\section{SUPPORT OF CHILDREN}

In two recent decisions Justice Peters was unable to find any justification for reading a judicial exception into California statutes which exempt public employees' pensions from execution for the enforcement of child support obligations. Ogle v. Heim ${ }^{122}$ involved a

community property. CAL. CIV. CODE $\S 163.5$ (West Supp. 1968). The wife, however, has the right to management of the amounts recovered for her injuries. See CaL. CIV. CodE $\$ 171 \mathrm{c}$ (West Supp. 1968).

117. But see H. ClARK, supra note 39, at 276-77, which mentions the opposite fear in some quartcrs that granting the wife the right to recover for loss of consortium might result in extravagant verdicts and rising insurance premiums.

118. 50 Cal. 2d 664, 667, 328 P.2d 449, 451 (1958).

119. Cal. Civ. Proc. Code $\S 427$ (West 1954); West v. City of San Dicgo, 54 Cal. $2 d$ 469, 353 P.2d 929, 6 Cal. Rptr. 289 (1960); Acadia, California, Ltd. v. Herbert, 54 Cal. 2d 328, 353 P.2d 294, 5 Cal. Rptr. 686 (1960).

120. See H. CLARK, supra note 39 , at 227-28.

121. $50 \mathrm{Cal} .2 \mathrm{~d}$ at $667,328 \mathrm{P} .2 \mathrm{~d}$ at 451 .

122. 69 Adv. Cal. I, 442 P.2d 659, 69 Cal. Rptr. 579 (1968). 
divorced wife's attempt to obtain execution on her husband's modest retirement allowance as a former county employee to satisfy a judgment for delinquent child support. The Justice carefully considered the statutory law, California precedents and the law of some other states, and found that the pensioners' exemption laws allow no exceptions. Although the Justice was well aware of the special place that care and support of children has in the law, he was also mindful of the need to protect old-age security systems not only for the benefit of a particular employee but also for the purpose of maintaining the financial security of the entire system. If exceptions in the exemption rule could be made, he felt, they would have to be carefully worked out by the legislature. ${ }^{123}$

Justice Peters' opinion in this unanimous decision, while it may perhaps be surprising on first sight, is entirely convincing, especially, as the Justice pointed out, since other remedies, including contempt, are available to enforce pensioners' child support duties.

In the companion case of Miller v. Superior Court ${ }^{124}$ Justice Peters reached the same result with respect to a different public retirement system, a much more generous pension, and an attempted execution to enforce both alimony and child support obligations. ${ }^{125}$

One of Justice Peters' forceful dissents, in the case of People v. Shirley, ${ }^{126}$ seems to have been instrumental in saving the state welfare system from a charge of illegality similar to the one made against the "substitute father" regulations in other states. The United States Supreme Court in King v. Smith ${ }^{127}$ declared Alabama's "substitute father" regulation invalid because of its inconsistency with the Social Security Act. One major reason for this decision was that the person chosen by the regulation to take the place of an "absent parent" was in no way obligated by state law to support needy children not his own. This was exactly the point Justice Peters had made in his dissent in Shirley seven years earlier. California did not have a "substitute father" regulation, but it had a "man-assuming-the-role-of-spouse" rule which at that time was merely a regulation promulgated by the Department of Social Welfare. The majority in Shirley upheld the regulation, which permitted the welfare department to consider the income of a man living with the mother and assuming the role of

123. Id. at 8, 442 P.2d at 663,69 Cal. Rptr. 583 (1968).

124. 69 Adv. Cal. 9, 442 P.2d 663, 69 Cal. Rptr. 583 (1968).

125. For another decision by Justice Peters on the enforcement of arrearages in child support payments, see Ford v. Ford, 144 Cal. App. 677, 301 P.2d 450 (1956).

126. 55 Cal. 2d 521, 360 P.2d 33, 11 Cal. Rptr. 537 (196I).

127. 392 U.S. 309 (1968). 
spouse in determining the aid to be granted to the mother's children. The regulation had been issued under the statutory provision which related to "stepfathers" only and imposed a duty of support of his wife's children on stepfathers if the children would otherwise require welfare aid. ${ }^{128}$

Justice Peters, incensed about the majority ruling, stated:

The effect of the majority opinion is to hold that the Board of Social Welfare, by a regulation adopted by it, can determine that a needy child, who is otherwise entitled to state aid, can be deprived of a certain portion of that minimum aid . . . solely because the mother is engaged in an extramarital relationship with a man who has no legal obligation to support the child, and who may in fact, legally refuse to do so.

...

... [T]he Legislature's intent was that aid is to be withheld from a needy child only when a person who is legally obligated to support the child, and is able to do so, refuses.

- $\cdot$

... [T]he reason why the Legislature provided that a stepfather's income may be used in computing the amount of aid granted to the child is that section 1508 carefully makes the stepfather legally obligated to support his stepchildren up to an amount representing his wife's community property interest in his income. ... But a "quasi spouse" has no legal obligation to support the child ....

It is unquestioned that any support actually provided to the mother from any source can and should be taken into consideration in computing payments. But, as one of the law review articles cited by the majority points out, these "common law" relationships often develop for the very reason that the man involved refuses to be obligated for the support of the children ....

It is for the Legislature and not the board to determine whether a needy child is to have his allotment curtailed because his mother is living with a man who assumes "the role of spouse," whether such a man shall be legally obligated to support the child, and whether the child shall receive ANC aid unless a legal stepfather relationship has been established. ${ }^{129}$

128. Cal. Welf. \& INST'NS CODE $\$ 1508$ (1954).

129. $55 \mathrm{Cal}$. $2 \mathrm{~d}$ at $527,529,530,360$ P.2d at 36, 37, 38, 11 Cal. Rptr. at 540, 541, 542 (emphasis by Justice Peters). Compare the companion case of People v. Bailey, 55 Cal. 2d 514, 360 P.2d 39, 11 Cal. Rptr. 543 (1961), in which Justice Peters went along with the majority because, unlike Shirley, the case involved the presumption of a marriage between the mother and the man with whom she was living. 
Thereupon, and perhaps because of this dissent by Justice Peters, the "stepfather" provision was amended"130 by adding language relating to the "male person assuming the role of spouse" and imposing on him a duty of support which equals that of the stepfather. ${ }^{13 t}$ This amendment would seem to meet the requirement of the United States Supreme Court in King v. Smith that any person who takes the place of an absent "parent" be "an individual who owed to the child a state-imposed legal duty of support." "132 Whether there are any constitutional objections to the amendment cannot be gathered from King $v$. Smith since that case was decided on a point of statutory interpretation of the Social Security Act $^{133}$ and did not reach the constitutional issue. At least two state appellate decisions have held the amendment constitutional. ${ }^{134}$

\section{VI}

\section{PUBLIC POLICY AND THE TERMINATION OF MARRIAGE}

In Maduro v. Maduro, ${ }^{135}$ decided in 1944, Justice Peters expressed the public concern for the preservation of marriages when he concluded that there can be no default annulments without the presentation of evidence to the court:

[W]e are convinced that, as a matter of public policy, and in order to protect the interests of the state in the marriage relationship, a trial court not only has the discretion to require the production of evidence in a default annulment, but that, in such a case, such court is without power to enter judgment without the production of evidence. Cases dealing with the dissolution or annulment of the marriage relationship are sui generis. The state is a silent but by no means inactive third party to every action to dissolve a marriage. The institution of marriage is of so much importance to society that the public is interested in the outcome of every action for an annulment. . . .

130. That there was a causal connection between Justice Peters' dissent in Shirley and the passage of the amending statute was presumed by the court in County of Kern v. Coley, 229 Cal. App. 2d 172, 177, 40 Cal. Rptr. 53, 56 (1964).

131. Ch. 2105, \& 1, [19611 Cal. Stats. 4369, amending CAL. WELF. \& INST'NS CODE $\$ 1508$, now Cal. WelF. \& INST'NS CODE $\S 1135$ I (West Supp. 1968).

132. 392 U.S. at 329.

133. Since the California statute was not before the United States Supreme Court in King v. Smith, it cannot be stated with absolute certainty that it would be upheld under the Social Security Act. The United States Department of Health, Education and Welfare has issued regulations under that Act which seem to be more stringent than King v. Smith would seem to require. See H.E.W. Reg. \& 203.I, 33 Fed. Reg. I1 290 (1968).

134. People v. Ford, 236 Cal. App. 2d 438, 46 Cal. Rptr. 144 (I965); People v. Rozell, 212 Cal. App. 2d 875, 28 Cal. Rptr. 478 (1963).

135. 62 Cal. Ápp. 2d 776, 145 P.2d 683 (1944). 
.. If annulments could be granted without production of evidence it would rest entirely within the power of the two parties to the marriage contract to secure an annulment upon the filing of a verified complaint and upon default of the defendant. The interests of the state in maintaining the marriage contract would in no way be protected. ${ }^{138}$

This case is also significant for the fact that it foreshadows the possibility of combining divorce and annulment actions into one single action, a proposal included in pending legislation in California. ${ }^{137}$

Judicial concern for the preservation of marriages has shifted its emphsis in recent years-particularly since the epochal opinion of Justice Traynor in De Burgh v. De Burgh $h^{138}$ - to what might be called the negative aspects of the public policy favoring the stability of families. After Justice Traynor in De Burgh eloquently described the basic value of the family as "the core of our society," "139 he continued with the famous statement that "Public policy does not discourage divorce where the relations between husband and wife are such that the legitimate objects of matrimony have been utterly destroyed." "I 40 And the Justice stated further: "The perpetuation of an unwholesome relationship would be a mockery of marriage." ${ }_{141}$ "lt is a degradation of marriage and frustration of its purposes when the courts use it as a device for punishment."1+2 Under this approach the public interest in the institution of marriage in general is sought to be protected by refusing to continue or prolong marriages which have totally failed or have irremedially broken down.

136. Id. at 779, 145 P.2d at 684-85. See also Difloe v. Difloe, 168 Cal. App. 2d 47, 335 P.2d 177 (1959), where Justice Peters, speaking for the court, reversed a divorce judgment for failure of the evidence to support the trial court's finding of cruelty.

137. See S.B. 252, Cal. 1969 Sess., introduced in January 1969, the so-called "Family Law Act" proposal, a modified version of the "Family Court Act" bill introduced in the California Legislature in 1967 and 1968. On this legislation, see generally Kay, A Family Court: The California Proposal, 56 CALIF. L. Rev. 1205 (1968); Dinkelspiel \& Gough, The Case for a Family Court-A Summary of the Report of the California Governor's Commission on the Family, 1 FAM. L.Q., Sept. 1967, at 70.

Such a development would, among other things, provide a solution for unfortunate cases like Middlecoff v. Middlecoff, 160 Cal. App. 2d 22, 324 P.2d 669 (1958), where Justice Pctcrs saw no way of awarding support money to a needy de facto wife whose 15-year marriage had been annulled on the ground of her husband's incompetency. See also Middlecoff v. Middlecoff, 167 Cal. App. 2d 698, 335 P.2d 234 (1959). Compare and contrast Justice Petcrs' disscnt in Keene v. Keene, 57 Cal. 2d 657, 668, 37I P.2d 329, 336, 21 Cal. Rptr. 593, 600 (1962).

138. 39 Cal. $2 d 858,240$ P.2d 598 (1952).

139. Id. at 864,250 P.2d at 601 .

140. Id. (emphasis added).

141. Id. at 867,250 P.2d at 603 .

142. Id. at $864,250 \mathrm{P} .2 \mathrm{~d}$ at 601 . 
This frank acceptance of divorce under certain circumstances as a useful and salutary instrument of public policy is reflected in two important decisions, one before and one after De Burgh, written by Justice Peters. In Angell v. Angell ${ }^{1 / 3}$ Justice Peters declared that it is an abuse of discretion for a court to refuse the entry of a final decree of divorce because of a trial reconciliation, attempted during the interlocutory period, which had ultimately failed. By refusing to permit a ruling to stand which would have returned the parties to a marriage situation already found to be hopeless, the Justice promoted the policy of favoring divorce when the marriage has in fact come to an end. But at the same time he furthered the positive policy of preserving marriages by removing an impediment to trial conciliations:

[I]t must be remembered that the main purpose of requiring the oneyear period to elapse ... is to give the parties an opportunity to think the matter over, to compose their difficulties, and to effect a reconciliation. . . . The state is interested in saving the marriage, if possible. That purpose would seldom be effectual if the innocent party could not dare try to effect a reconciliation at the peril of losing the right to secure a final decree."H

In the second case, Hull v. Superior Court, ${ }^{145}$ Justice Peters dealt with another problem involving the right to a final decree of divorce. Mr. Hull had not complied with the property terms of an integrated property settlement agreement which had been incorporated into the decree of divorce; in addition, he had gone through a Mexican marriage ceremony soon after the initial decree and was living with his new "wife." Justice Peters held that neither the breach of the property agreement nor "remarriage" during the interlocutory period were proper grounds for withholding entry of the final decree. Relying heavily on De Burgh and the policies with respect to marriage and divorce laid down in that decision, the Justice declared that it is the public policy "not to discourage final and permanent severance of marriages that have failed;" that the "public interest is not enhanced by refusing people the right to legally terminate a relationship which has already been irrevocably severed in fact;" "1+6 that it "is no longer a sufficient basis for denying an interlocutory decree that the petitioner is also found to be at 'fault;" "', and that entry of the "final decree is not a reward for good behavior." ${ }^{1+8}$

143. 84 Cal. App. 2d 339, 191 P.2d 54 (1948).

144. Id. at 343, 191 P.2d at 57.

145. 54 Cal. 2d 139, 352 P.2d 161, 5 Cal. Rptr. 1 (1960).

146. Id. at 145, 352 P.2d at 164, 5 Cal. Rptr. at 4-5.

147. Id. at 146, 352 P.2d at 164, 5 Cal. Rptr. at 5 .

148. Id. at 149,352 P.2d at 167,5 Cal. Rptr. at 7. 
Both cases illustrate the fact that the interlocutory period may do more harm than good. Another line of cases, of which Wilson $v$. Wilson $^{199}$ by Justice Peters, is an example, also demonstrates this point. It deals with the question of whether the property division upon divorce may or may not be made immediately effective upon entry of the interlocutory decree. The matter is not yet finally settled..$^{150}$ The solution for these and other problems created by the interlocutory period would seem to be abolition of the period itself, a reform proposed in pending family law legislation. ${ }^{151}$

Cases like Angell and Hull, read together with De Burgh, have helped immeasurably to speed up the process of removing antiquated growth from the body of California divorce law. Many of the old doctrines are now leading but a shadow existence. The point is nearing at which the legislature must clear away the debris and start afresh. Whether the means devised to break down the outdated notions can also serve the purpose of building a new system, is an entirely different question. ${ }^{152}$ It remains to be seen whether the principle, which was designed to remove objections to separation agreements, ${ }^{153}$ to eliminate the ancient notion of recrimination, ${ }^{154}$ and to lessen the impediment of the interlocutory period, ${ }^{155}$ also lends itself to distinguishing between those marriages which are so hopelessly disrupted that they must be terminated and those which have sufficient life and positive value left that they can and should be preserved. ${ }^{156}$

In the judicial opinions discussed in this Article, as in many others, Justice Peters reveals himself as a master of legal reasoning who has played an important role in clarifying essential areas of California family law, in reconciling divergent viewpoints, and in settling doubtful questions of law. Beyond these predominantly "legal" achievements, the Justice demonstrates a keen awareness of the social and human problems involved in the cases, and a desire to

149. 76 Cal. App. 2d 119, 172 P.2d 568 (1946).

150. See 1 ARMStrong, supra note 3, at 839-43. See also id. at 246-50 (Supp. 1966).

151. See note 137 supra.

152. On this question see Bodenheimer, Reflections on the Future of Grounds for Divorce, 8 J. FAM. L. 179, 193-207 (1968).

153. Hill v. Hill, 23 Cal. 2d 82, 93, 142 P.2d 417, 422 (1943).

154. De Burgh v. De Burgh, 39 Cal. 2d 858, 250 P.2d 598 (1952).

155. Hull v. Superior Court, 54 Cal. 2d 139, 352 P.2d 161, 5 Cal. Rptr. 1 (i960).

156. S. B. 252, Cal. 1969 Sess., provides, in the form it passed in the California Senate on April 10, 1969: "TTlhe court shall render its judgment decreeing the dissolution of the marriage ... unless it finds that the legitimate objects of matrimony have not heen destroyed . ..." Id. § 8, proposed CAL. CIV. CODE § 4615(a). 
help move the law forward toward more realistic and more equitable solutions of basic policy questions. In his work as an appellate and supreme court justice, Justice Peters has helped prepare the ground for a better family and community property law of the future. 